\title{
Ethics
}

Socially Responsible Business and Management of Contemporary Organization

The Phenomenon of Greenwashing in Marketing Communication of CSR

Indicating Sustainability in Bookkeeping Systems - a Reference Frame and Implementation for SMEs under the Perspective of an Ethical Change (de: Zur Abbildung der Nachhaltigkeit im Rechnungswesen - ein Bezugsrahmen und Operationalisierungsvorschläge für den Mittelstand unter einer sich wandelnden Ethik)

CSR and Innovativeness of the Organisation

Infobrokering: an Ethical Challenge in the Knowledge-Based Economy

Profit Maximization from the Perspective of Ethics (de: Die Gewinnmaximierung aus der Sicht der Ethik) 



\section{Socially Responsible Business and Management of Contemporary Organization}

Keywords: Corporate Social Responsibility, management, manager

Słowa kluczowe: Społeczna Odpowiedzialność Biznesu, zarządzanie, menedżer

\section{Introduction to management}

Generally, 'management' can be defined as knowledge which is a part of economics. It is a process "focusing on implementation of goals, in particular through planning, work organization, efficient decision making, motivating and controlling. An important property of management is a rational use of resources (people, fixed, financial and intangible assets)."

A similar approach to management has been taken by Koźmiński and Jemielniak. In their opinion, "management involves ensuring (creating) conditions so an organization can operate according to its objectives to implement its mission, reach relevant goals and maintain necessary cohesion helping it to survive." "2 The definition highlights one very important feature of management related to profitability. It is important since each entity interested in corporate social responsibility needs to communicate the significance of its goals. In the CSR concept, economic goals still remains crucial, whereas social ones are subordinate to the former. It is so because in the free competition context, a company

\footnotetext{
* mgr Marcin Janowski, Katedra Ekonomii, Wydział Zarządzania i Ekonomiki Usług, Uniwersytet Szczeciński, marcin.janowski@wzieu.pl

1 M. Brojak-Trzaskowska, Wybrane koncepcje w zarządzaniu wspótczesnymi przedsiębiorstwami, in: Zarzadzanie przedsiębiorstwem, ed. J. Engelhardt, CeDeWu, Warszawa 2014, p. 9.

2 A.K. Koźmiński, D. Jemielniak, Zarządzanie od podstaw, Wydawnictwa Akademickie i Profesjonalne, Warszawa 2005, p. 16.
} 
needs to ensure its profitability, otherwise it will not withstand the omnipresent competition, and it will not be able to implement corporate social responsibility goals. The above has been highlighted since in various communities, especially those representing practitioners, various false stereotypes still exist. It is sometimes claimed that social goals should be considered first and the proper management of economic goals seems to be forgotten. Such opinions are sometimes justified by misinterpreted concepts of social goals. An example of that is the analysis of social enterprise goals, ${ }^{3}$ mistaken with the concept of the corporate social responsibility. The former indeed define social goals as the most important. It should be added, however, that the operation of social enterprises does not always depend on their competitive position on the market, but on the provision of external funding. Such financial arrangements are not available for the corporations implementing the CSR concept, since they need to generate the necessary funding from the market by themselves. The hierarchies of CSR and the social enterprise goals are compared in Figure 1.

Figure 1. Hierarchies of social enterprise and corporate social responsibility
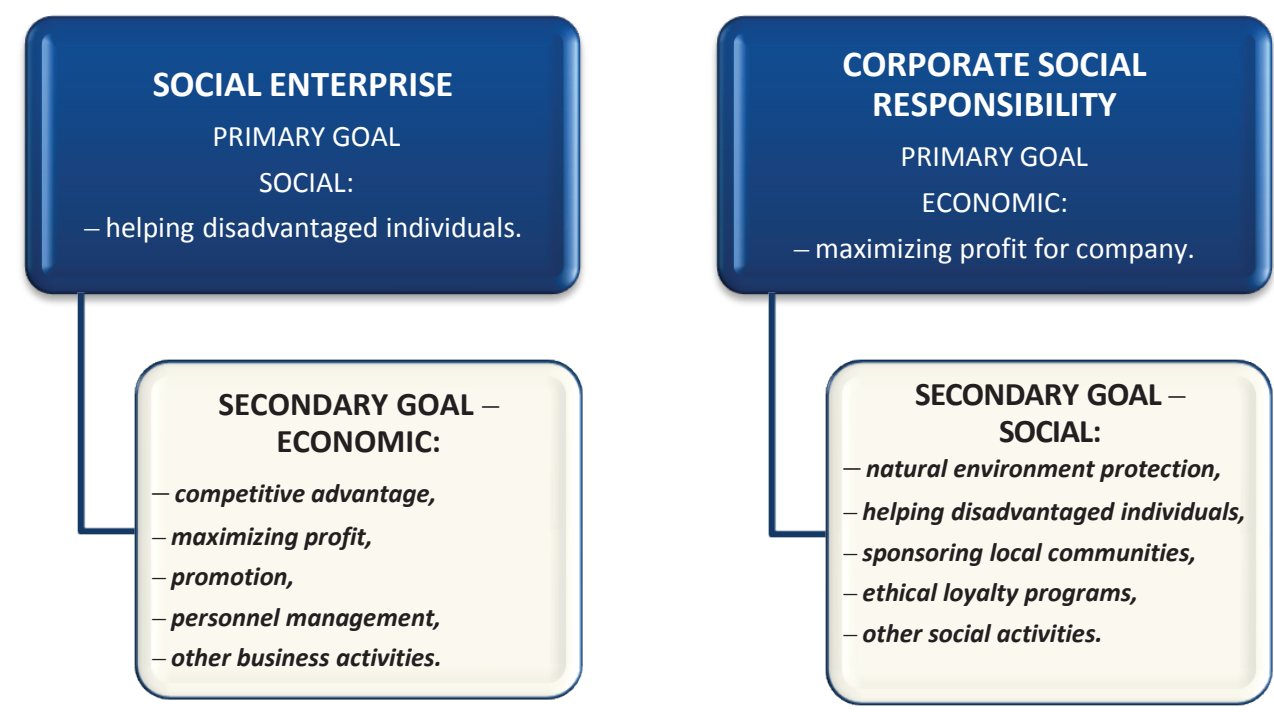

Source: materials developed by author.

\footnotetext{
3 Social enterprise referred to as social economy or economy of solidarity, as it was described by Babis, is "(...) a sector of the economy in which organizations focus on their social usability and their surplus is used for implementing a social goal.” Source: Zarządzanie podmiotami ekonomii społecznej, ed. H. Babis, Polskie Towarzystwo Ekonomiczne, Szczecin 2013, p. 11.
} 
The best example summarizing the significance of the economic goals in CSR has been expressed by Drucker. "If managerial posts were occupied not by businessmen but archangels, they would have to take care of profitability despite being completely disinterested in profit making." 4 For this reason, proper management in an organization struggling against free competition (regardless of its operating concept) is necessary, and the relevant knowledge helps to reach goals more efficiently (including the corporate social responsibility goals). Rapid external and internal changes in business organizations determine an important task for contemporary managers. As Parker puts it, "management never ends, it must continue while implementing activities aimed at organizing a system which steadily tends to disorganize itself." 5

From the point of view of the managerial staff implementing corporate social responsibility objectives, it is worth quoting one more definition which highlights the economic and social dimension of CSR. It was formulated by Koźmiński, who wrote that "the core of management is harnessing diversity and transforming conflicts into cooperation to ensure the survival and development of an organization, including the relationship with its environment."' Such an approach to management helps to highlight the issues fitting into the CSR concept (protecting the environment or helping the socially and economically disadvantaged people).

Apart from the attempt to define management, it is necessary to refer to some major features of the process. They should provide a better description of the term of management, and examine the areas where we can find references to social issues, typical for CSR. Those basic features of management include:?

a) placing management processes in a socio-geographic context which necessitates considering ethics, norms of conduct, group culture (ethnic, national, and ideological groups);

b) focusing on a man, which translates into the awareness of the fact that a man always stands behind the success of an organization, a man who can be educated and deal with tasks in line with their psychophysical skills and experience;

c) creating systems of internal and external communication in an organization, which determine success, both economic and social;

d) implementing one of the basic goals, that is a positive relationship with the customer, since a market success is closely linked with attracting customers and main-

${ }_{4}$ M. Żemigoła, Społeczna odpowiedzialność biznesu. Budowa zdrowej, efektywnej organizacji, Wolters Kluwer, 2007, p.15.

5 M. Parker, Against Management, Polity Press, Cambridge 2002, p. 62.

6 A.K. Koźmiński, Zarządzanie, in: Zarządzanie. Teoria i praktyka, eds. A.K. Koźmiński, W. Piotrowski, PWE Warszawa 2002, p. 57.

W. Maziarz, Zarządzanie, przywództwo, lider i menedżer w podmiotach ekonomii społecznej, in: Menedżer ekonomii społecznej, ed. H. Babis, PTE, Szczecin 2013, p. 46. 
taining relations with them, and the activity related to it should take into account the customers' needs;

e) observing the surroundings and drawing conclusions to build up knowledge, acquire new competences, and adapt the organization to ever changing conditions;

f) selecting tasks and determining goals and values (including social ones) as the guiding principles for organization stakeholders.

As specified above, management cannot focus on just one selected aspect, but it needs to be more universal. It is not possible to separate the rules dedicated solely to social responsibility, since management is applicable to all business that represents various concepts. It is possible to claim that in the case of CSR, certain issues will be more relevant than others. In particular, they include those that fit into the concept of sustainable development.

\section{Organizational culture and management}

It needs to be mentioned that organizational culture is one of the major factors determining management processes in organizations. It influences the nature of an organization, and creates a basis for formulating its mission, and, as such, shapes its strategy. Therefore, it influences the nature and type of decisions made by managers.

In general, organizational culture can be described as the 'identity' of a company. It is believed that the term 'organizational culture' was formed by Jacques, a Canadian psychologist and doctor, The term was used for the first time in the first half of the $20^{\text {th }}$ century, whereas the researchers in the field of economy and management started using the term in the 1970s and 1980s. Nowadays, we have a number of definitions of the term. For the purpose of this article, it is justified to quote those which refer to social and management issues. According to Schein, organizational culture is "a pattern of shared basic objectives defined while solving problems, which are efficient enough to consider them valuable and worth promoting among new members of the organization as a desired attitude, mode of thinking and perceiving problems." " This approach highlights those qualities of management processes in an organization, which are worth examining in a wider context of their social dimension. An example of this approach can be seen in the definition by Sikorski, who believes that "organizational culture is a system of thinking and behavior patterns that are important for the implementation of formal goals of an organization, patterns which are informally rooted in the social environment of that or-

8 E. Schein, Coming to a New Awareness of Organizational Culture, "Sloam Management Review" 1984, no. 25, p. 12. 
ganization." While linking the social aspect with elements of management in a similar manner, Czerska presented organizational culture describing it as "a set of social norms and value management systems that stimulate behavior of organization members and are important for the implementation of a specific goal." ${ }^{\prime 10}$ It is clear that since organizational culture has a strong influence on the management processes in a company, it needs to be taken into consideration by managers while formulating strategies. It seems to be particularly important to consider organizational culture from the point of view of corporate social responsibility. It results from a specific nature of CSR goals, which include environmental protection, equal rights, and internal and external ethical relations. Such goals form a foundation of culture of any community operating in its socio-economic environment, and, as such, exert strong influence on the culture in an organization. It can be concluded that the development of organizational cultures in the context of CSR marks a return to the values which became marginalized in many organizations due to globalization, commercialization, and moral deterioration caused by political elites and an ethical crisis in business. As highlighted by Penc, ethical attitudes and social responsibility should not be strange to business decision makers, and "ethics should be fitted into the culture of a company as an important set of values, norms and behaviors (...). Cultural ways play an important role in determining the behavior of managers (...) and their awareness of relations between success of an organization and its environment." ${ }^{\prime \prime}$ Environmental, ethical and social behaviors are closely linked with the expectations expressed by the internal and external environment of an organization. Therefore, the incorporating of the corporate social responsibility concept into the organizational culture seems natural, and, as emphasized by a number of researchers, unavoidable if the socio-economic environment should develop towards the equality and fair treatment of all parties involved.

Organizational culture develops under the influence of several factors, which can be divided into endogenous (internal) and exogenous (external) ones. The former include, among others, the cultural tradition of an organization, the organizational solutions implemented so far, and the managerial staff, whereas exogenous factors comprise social development and historical experience, as well as demographic, geographic, and religious conditions. Both external and internal factors are presented in Table 1.

9 C. Sikorski, Kultura organizacyjna. Efektywnie wykorzystaj możliwości swoich klientów, C.H. Beck, Warszawa 2006, p. 31.

10 M. Czerska, Zmiana kulturowa w organizacji, Difin, Warszawa 2003, p. 11.

11 J. Penc, Menedżer w działaniu. Sekrety prowadzenia biznesu, C.H. Beck, Warszawa 2003, p. 79. 
Table 1. Endogenous and exogenous factors influencing organizational culture

\begin{tabular}{|l|l|}
\hline \multicolumn{2}{|c|}{ Organizational culture } \\
\hline Endogenous factors & Exogenous factors \\
\hline cultural tradition of organization & social development and historical experience \\
\hline existing organizational solutions & demographic conditions \\
\hline managerial staff & religion \\
\hline
\end{tabular}

Source: author based on K. Kubik, Menedżer w procesie zarządzania zasobami ludzkimi, Wydawnictwo Menedżerskie PTM, Warszawa 2012, p. 221.

The factors influencing organizational culture can be classified from the point of view of the environment, organization, and stakeholders. With this respect, internal factors include those pertaining to the organization itself, and those related to the internal stakeholders. A detailed division of the factors is given in Table 2.

Table 2. Factors influencing organizational culture from the point of view of environment, organization and stakeholders

\begin{tabular}{|c|c|c|}
\hline \multicolumn{3}{|c|}{ Organizational culture } \\
\hline Environment & Organization & Stakeholders \\
\hline social and cultural & vision and mission, & cultural values \\
\hline economic legal regulations & history of companies & needs \\
\hline technology & size of organization & experience \\
\hline sector & organization strategy & \multirow{4}{*}{ education level } \\
\hline \multirow{3}{*}{ competition structure } & organization structure & \\
\hline & technology used & \\
\hline & management style & \\
\hline
\end{tabular}

Source: author based on G. Aniszewska, I. Gielnicka, Firma to ja, firma to my, Ośrodek Doradztwa i Doskonalenia Kadr, Gdańsk 1999, p. 44.

The factors listed above can also be divided regarding their economic and social influence on organizational culture. The former include those that depend on the specific nature of the market, such as the size of an organization, market structure, technology, and organizational structure, whereas the latter include social and cultural environment, cultural values, and the stakeholders' needs. The division is indeed important from the point of view of implementing the CSR concepts. The first group includes the factors that can be influenced by managers while shaping organizational culture in the context of social responsibility. Social factors, however, remain beyond the influence of managers although they determine their decisions to a large extent. The factors are usually closely linked with the principles of ethics or good conduct, and thus naturally fit into the concept of corporate social responsibility. It may also be noticed that there are those factors which can neither be included in the first nor the second group, such as the company mission or the history of an organization, since they result partially from the economic, and, to a certain extent, from the social goals. 
Organizational culture is one of the foundations of the management process, and has a strong influence on the business activity, especially in the context of CSR. The ability of developing an appropriate culture in a company has become necessary while planning and implementing selected strategies by managerial staff. The number of social factors influencing organizational culture is so large that managers while implementing the corporate social responsibility concept need to pay particular attention to shaping relevant attitudes and behavior. The values and attitudes shared by employees should be developed in such a way that the culture of a socially responsible organization becomes the foundation of personal values and the culture of the organization members.

\section{Conclusion}

Contemporary business is responsible business, and the role of a manager involves searching for synergies between economic, social, and environmental objectives. This should result in building company development strategies based on the corporate social responsibility concept. This should also generate measurable benefits for the organization. In the internal context, it may include, for example, the possibility to reduce administrative tasks in the result of the voluntarily assumed ethical obligations or conflict free management of the organization. As for the external context, CSR activity (in longer term) may help implementing more complex, even macroeconomic goals (improved social responsibility and cohesion, enhanced innovation of the economy, responsible use of resources and integration with labor market). ${ }^{12}$ In the light of the above, the role of a socially responsible manager is fully justified, since mere acknowledgement that CSR is the right, proper, and desired concept is insufficient. It should also be taken into consideration how to implement and use it efficiently to promote synergies between social and economic goals.

\section{Literature}

Czerska M., Zmiana kulturowa w organizacji, Difin, Warszawa 2003.

Koźmiński A.,K., Jemielniak D., Zarzadzanie od podstaw, Wydawnictwa Akademickie i Profesjonalne, Warszawa 2005.

Maziarz W., Zarzadzanie, przywództwo, lider i menedżer w podmiotach ekonomii społecznej, in: Menedżer ekonomii spolecznej, ed. H. Babis, PTE, Szczecin 2013.

Parker M., Against Management, Polity Press, Cambridge 2002.

Penc J., Menedżer w działaniu. Sekrety prowadzenia biznesu, C. H. Beck, Warszawa 2003.

12 Spoleczna Odpowiedzialność Przedsiębiorstw (CSR), Ministerstwo Gospodarki, www.mg.gov.pl (10.02.2015). 
Schein E., Coming to a New Awareness of Organizational Culture, "Sloam Management Review" 1984, no. 25.

Sikorski C., Kultura organizacyjna. Efektywnie wykorzystaj możliwości swoich klientów, C.H. Beck, Warszawa 2006.

Społeczna Odpowiedzialność Przedsiębiorstw (CSR), Ministerstwo Gospodarki, www.mg.gov.pl. Zarzadzanie przedsiębiorstwem, ed. J. Engelhardt, CeDeWu, Warszawa 2014.

Zarzadzanie. Teoria i praktyka, eds. A.K. Koźmiński, W. Piotrowski, PWE, Warszawa 2002.

Żemigoła M., Społeczna odpowiedzialność biznesu. Budowa zdrowej, efektywnej organizacji, Wolters Kluwer, 2007.

\begin{abstract}
Management of businesses in the times of rapid and unpredictable changes, while striving for efficient implementation of statutory goals and maintaining economic efficiency, is a complex and uneasy task. Provided that managers want a company to implement not only business, but also social goals that fit into the broad concept of Corporate Social Responsibility, the process seems even more difficult. For this reason, it is important that contemporary managers should have versatile knowledge on management which deals with creating methods of effective and efficient implementation of business goals.
\end{abstract}

\title{
Społecznie odpowiedzialny biznes w zarządzaniu współczesną organizacją
}

Zarządzanie organizacją w dobie dynamicznych i trudnych do przewidzenia zmian, przy dążeniu do skutecznej realizacji przyjętych celów statutowych i zachowania efektywności gospodarczej, to zadanie skomplikowane i niełatwe. Jeżeli do tego zarządzający będą chcieli, aby ich podmiot realizował nie tylko cele ekonomiczne, ale również społeczne, wpisujące się w szeroko rozumiana koncepcję Corporate Social Responsibility, to wybór takiej drogi wydaje się zadaniem jeszcze trudniejszym. Dlatego ważne jest, aby współcześnie zarządzający wyposażeni byli w multidyscyplinarną wiedzę, będącą podstawą nauki zwanej zarządzaniem, zajmującej się tworzeniem metod skutecznego i sprawnego realizowania celów podmiotów gospodarujących. 